\title{
Mission in Higher Education in Slovenia: Sustainability in Engineering versus Others Sector
}

\author{
Kristijan Breznik ${ }^{1,2, *(\mathbb{D})}$, Kris M. Y. Law ${ }^{3} \mathbb{D}$ and Jasmina Zeme ${ }^{1}$ \\ 1 International School for Social and Business Studies, 3000 Celje, Slovenia; jasmina.zeme@mfdps.si \\ 2 Environmental Protection College, 3320 Velenje, Slovenia \\ School of Engineering, Deakin University, Geelong, VIC 3220, Australia; kris.law@deakin.edu.au \\ * Correspondence: kristijan.breznik@mfdps.si
}

Citation: Breznik, K.; Law, K.M.Y.;

Zeme, J. Mission in Higher Education in Slovenia: Sustainability in Engineering versus Others Sector. Sustainability 2021, 13, 7947. https:// doi.org/10.3390/su13147947

Academic Editor: Barbara Motyl

Received: 4 June 2021

Accepted: 13 July 2021

Published: 16 July 2021

Publisher's Note: MDPI stays neutral with regard to jurisdictional claims in published maps and institutional affiliations.

Copyright: (c) 2021 by the authors. Licensee MDPI, Basel, Switzerland. This article is an open access article distributed under the terms and conditions of the Creative Commons Attribution (CC BY) license (https:/ / creativecommons.org/licenses/by/ $4.0 /)$.

\begin{abstract}
With the proper mission, higher educational institutions can search for their opportunities and eliminate their weaknesses in the market. In the paper, mission statements from engineering institutions are compared with other higher educational institutions in Slovenia. Results of the content analysis reveal that "development", "education", "research" and "knowledge" are words with the highest frequency, confirming similar studies in the past. Dimensions of sustainability are not equally distributed in mission statements of engineering and other institutions. The dimension of environmental sustainability is more exposed in engineering higher education institutions. On the other hand, the dimension of social sustainability is more exposed in non-engineering (others) higher education institutions.
\end{abstract}

Keywords: mission statements; sustainability; content analysis; network analysis

\section{Introduction}

The creation of a mission is the starting point of formulating a strategy in any institution [1]. Moreover, according to Kosmützky and Krücken [2], mission statements allow higher education (HE) institutions to position themselves in particular niches by distinguishing themselves from others. Following the proper mission, HE institutions can search for their opportunities and eliminate their weaknesses in the market. This paper aims to highlight differences between the content of mission statements in HE institutions in the engineering and non-engineering (other) sectors in Slovenia.

Engineers are vital to any prospering society and the effective training of the next generation of engineers is therefore crucial to the development of engineering schools in the higher education sector. Much research done on the subject has also proven that engineering schools have different specific strategies according to their disciplinary nature $[3,4]$.

The paper is organized in the following way. The rest of this Introductory part is divided into subsections dealing with mission statements in HE and sustainability. The description of Materials and Methods is followed by the Results section. In Discussion and Conclusions, results are evaluated and compared with previous findings. In addition, some ideas for future work are delivered, which concludes the paper.

\subsection{Mission Statement}

Since the early 1970s, mission statements have a key place in the institutional strategic planning process [5] and have been considered to be a key management tool [6]. Drucker [7] defines mission statement as the foundation for priorities, strategies, plans and work assignments. The format of a mission statement suggests an action, unclearly identifies this action and includes a social categorization [8]. A mission statement is an important tool for communication within an institution and outside the institution [5], to represent what the firm is about to stakeholders [9]. It articulates the management's beliefs, perspectives and approaches in regard to institutional purpose, social responsibility and achievable goals [10]. 
A well-crafted mission statement can provide many advantages to an institution [11]. It raises current performance and improves future performance [10]. In the late 1980s, Pearce and David [12] demonstrated a link between mission components and institutional performance. Bart [6] found a more significant relationship between various mission components and some other, non-financial performance measures such as employee behavior, satisfaction with the mission and commitment to the mission. Nevertheless, other research has confirmed a significant link between the mission statements and financial performance [5,13]. Mission statements are effective because of their unique ability to motivate the employees [5]. Institutions with a strong mission are more likely to retain current employees, promote managers within the institution and have less debt [10].

Higher education institutions, decades ago, were able to survive well without missions in relatively stable circumstances, according to Peek [14]. Throughout the years of technological and social development, the mission of public institutions has become more critical. Mission statements as part of strategic management in higher education institutions have been adopted from business [15]. The first mission statements across higher education institutions were published by U.S. universities in the early 1930s, followed by other universities, to prove their responsibility to the public [16]. In the mid-1990s, $80 \%$ of higher education institutions were making major revisions to their mission statements to obtain legitimacy [17].

The mission of universities is dynamic and fluid, reflecting the changing philosophical ideals, educational policies and cultures of particular societies or educational institutions [16]. An institution's mission statement represents a consensus on campus-wide values, expectations for student learning and development and a statement of campus priorities for many years in the future [18]. According to Fugazzotto [19], the mission of higher education institutions must take into account a typology of mission elements defined by Kotler \& Fox: institutional history, constituencies, environment, resources and distinctive competencies. Today's mission statements of higher education institutions are based on the triad mission of the university: teaching, research and public services [16]. Missions of modern HE institutions are more complex than just a creation and transmission of knowledge. For instance, missions of American HE institutions include generation of jobs, a mainstay of the local economy, a source of class maintenance, a place of cultural transmission and a vehicle for class transcendence [20]. Some university members advocate sustainability as one of the core values of their university and aspire to amend the university mission statement to include sustainability [21].

\subsection{Sustainability}

Sustainability is defined, by the Brundtland Commission of the United Nations, as "development that meets the needs of the present without compromising the ability of future generations to meet their own needs" [22]. This definition has been presented in many official agendas in the private, government and educational sectors [21].

Education has been identified as an essential tool for achieving sustainable development across the world [23], as "sustainable education" encourages changes in behavior that create a more sustainable future in terms of environmental integrity, economic viability and just society for present and future generations. "Sustainability education" has been introduced in Agenda 21 of the United Nations (U.N.) document, and the U.N. Assembly has declared 2005 through 2014 the United Nation Decade for Education for Sustainable Development [24].

To move towards sustainability, each university should define its concept and definition of a sustainable university. There is no precise orientation on precisely what a sustainable university should be. Only a few institutions have included sustainability in their mission statement [21].

According to many studies, only a few universities include clear sustainability aspects in their mission statements [23,25-27]. Arcimaviciene [23] analyzed the mission statements of 20 European Universities and found that some universities have some features of sustainability in their mission statements. The significant commitment of Australian universities to sustainability from the 20 sustainability themes were identified using web content analysis 
among 39 universities [25]. Deus et al. [26] concluded that a small percentage of Brazilian colleges and universities include language reflecting sustainability in their respective mission statements. In a content analysis of 347 mission statements, $19 \%$ of universities included at least one phrase related to sustainability in their mission statement [27].

Sustainability is a multi-dimensional concept interconnecting economic, socio-cultural and environmental components [28]. It consists of three main dimensions: environmental, economic and social [21,29]. These three pillars of sustainability can also be presented as "planet, profit and people" [30].

Environmental sustainability is synonymous with environmental protection [31]. It focuses on the land use changes, changes at the watershed scale and climate changes [32]. With regard to environmental sustainability, organizations report on emissions and energy consumptions [29]. Economic sustainability topics are of increasing importance for organizations. It refers to practices that support long-term economic growth, and its reporting is based on financial data [29]. Social sustainability is a component of a community's wellbeing and has four dimensions: quality of life, equality and diversity, social cohesion, democracy and governance [30]. It focuses also on labor practices, stakeholder involvement and sponsorship activities [29].

Sustainability in the engineering sector has been addressed in the literature in the past. According to Rosen [33], sustainability in the engineering sector is indispensable for overall sustainability; however, sustainable engineering approaches have been largely limited to technical measures [34]. As far as education engineering in concerned, engineering professionals need to have not only a set of deep capabilities in a specific area, but also more comprehensive proficiencies [35].

Based on the theoretical framework described above, we postulated following research questions and hypotheses:

RQ: What is the content of mission statements of HE institutions in Slovenia?

Hypothesis 1 (H1). Dimensions of sustainability are equally distributed in mission statements of Slovenian HE.

Hypothesis 2 (H2). Mission statements in engineering HE have different sustainability focuses in comparison to non-engineering $H E$.

From H2, two sub-hypotheses can be delivered:

Hypothesis 2a (H2a). Dimension of environmental sustainability is more exposed in engineering HE institutions.

Hypothesis $\mathbf{2} \mathbf{b} \mathbf{( H 2 b )}$. Dimension of social sustainability is more exposed in non-engineering (others) HE institutions.

\section{Materials and Methods}

Mission statements were collected directly from websites of Slovenian HE institutions. HE institutions in Slovenia include universities, faculties, art academies and colleges, and are entered into the register of MIZŠ (Slovenian Ministry of HE). If universities are divided into faculties, only mission statements from the latter were investigated. For 13 institutions (representing $8.8 \%$ of all HE institutions in Slovenia), we did not find a mission statement published on their websites. Therefore, the final list of institutions in our study included 93 institutions of Slovenian HE (91.2\%), which were classified into engineering institutions (29 institutions out of 93 or $31.2 \%$ of all institutions from which we were able to collect a mission statement) and other institutions (64; 68.8\%).

Collected missions were enshrined in declarations, which do not only mutually differ in terms of content, structure or scope. Some HE institutions recorded their missions, more generally, in ways that were extremely minimalist, even in just one sentence; however, some were more detailed and extended to half a page or more. All mission statements were collected in the original version, in the Slovene language. Therefore, translation was 
needed. It was necessary that written mission statements had adequate structure in order to apply quantitative analytic procedures.

After translation of the mission statements from Slovene into English, all uppercase letters were converted into small captions, all punctuation was removed, as well as numbers and redundant space, i.e., double spaces or lines. Words without a substantive interest, so-called stop-words, were removed. Words with the same meaning (synonyms) were replaced by a word with the most common use. Remaining words were analyzed in the first phase of the study with methods of simple descriptive analysis.

In the next step, a network of the most important words was established. In general, a network is identified with a set of actors and described with relations among them. In our case, actors have been selected as words from mission statements of HE institutions and a relation has been defined as co-occurrence of two words in the same mission statement. This kind of network can be classified as a non-directed and weighted network. The first property is straightforward, however, weights on links between two words are counting how many times two words occur together in the same mission statement(s). It is clear that weights are limited with integers between zero and the number of all mission statements in our study.

Similar methods for analyzing documents were already used in [36]. For preparation and analysis of mission statements, and for word counting, a statistical program $\mathrm{R}$, with its package tm [37], was used. Network analytic procedures were applied using R and Pajek [38], and, later, a program for analyzing and visualizing networks. For visualization, VOSViever [39] was also used.

\section{Results}

After cleaning, we were left with 1179 different words that assembled the mission statements of 93 Slovenian HE institutions. A word can occur in any mission statement more than once. For our purposes, we have counted multiple occurrences only once (unique occurrence). Frequency distributions of unique occurrences are displayed in Figure 1.

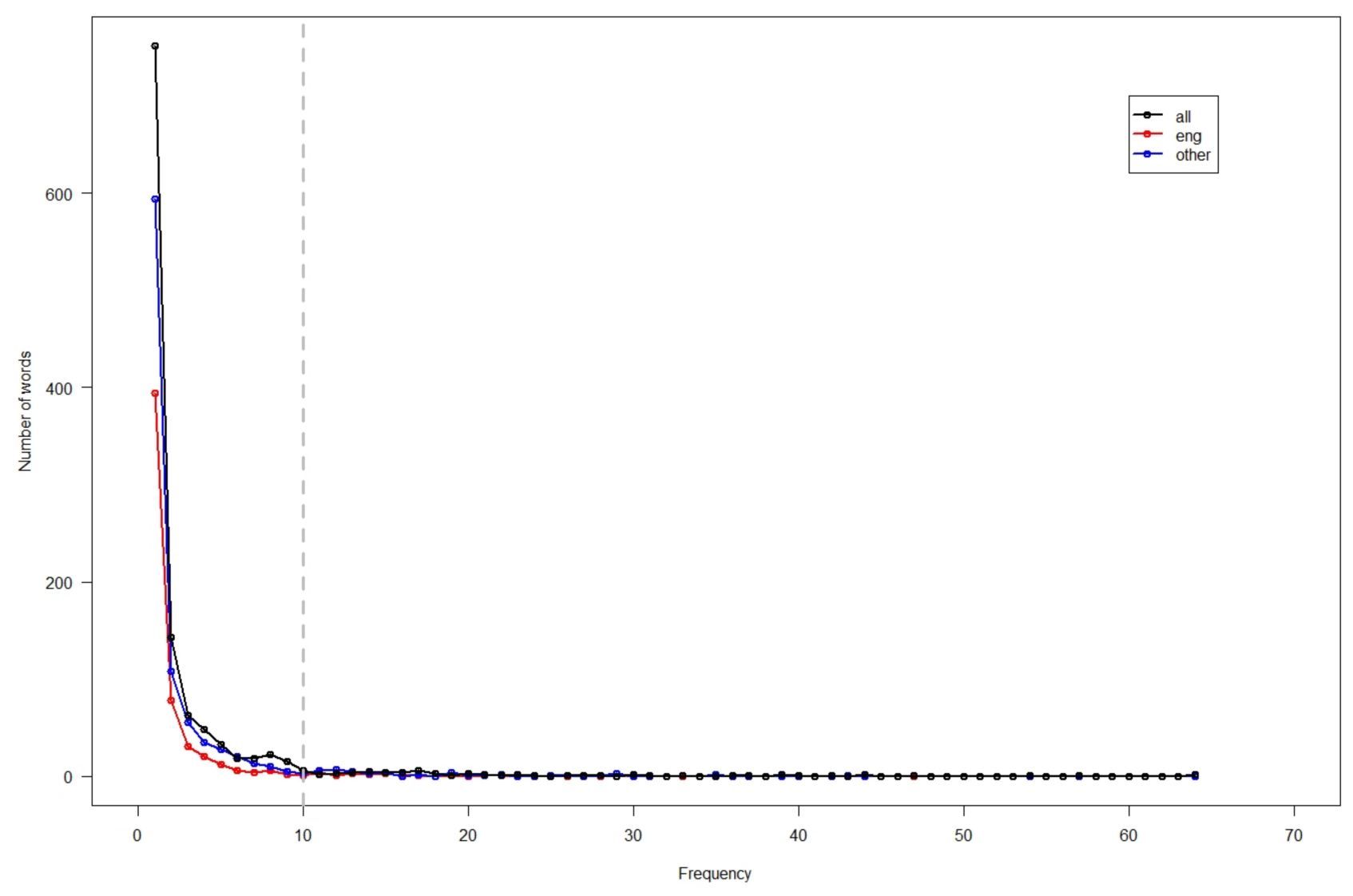

Figure 1. Distribution of words per mission statements in Slovenian HE institutions. 
In Figure 1, we can observe tree distributions displaying how many words occur in different mission statements. The first distribution (colored black) represents all mission statements (engineering and others), distributions representing engineering and other mission statements are colored red and blue, respectively. All three distributions in Figure 1 are examples of very quickly decreasing functions. We can observe many words that occur in only one mission statement. For instance, more than 700 words occur only once in mission statements of Slovenian HE institutions in general (app. 600 in other and app. 400 in engineering mission statements). The highest frequency is 64 and is achieved by the words "development" and "education", followed by "knowledge" (57) and "research" (54).

Based on Figure 1 and previous studies [40,41], the set of words was cut at a frequency of 10 (vertical dash grey line in Figure 1), i.e., only words that occur in at least 10 mission statements were left in the study. It turned out that 65 keywords have satisfied the described condition.

\subsection{Frequency Analysis of Keywords}

For each keyword, we calculated relative frequency of occurrence in both engineering and other networks of mission statements. Differences between relative frequencies are displayed in Figure 2 with a Dumbbell chart and are ordered from highest to smallest difference. On the top we can find the keyword "economy", which suggested that economy is far more frequent in mission statements of engineering HE institutions compared to the network of other HE institutions in Slovenia. Similarly, we can affirm the same for "knowledge", "creation", "transmission", "technology" and other keywords at the upper part of Figure 2. Words in the bottom part, for instance "contribution", "teacher", "development", "organization", etc., are more common in other mission statements. Two keywords, "community" and "work", have the same relative frequencies in both groups of mission statements. In addition, the position of the line representing a difference between both relative frequencies is also interpretative. Keywords with the line placed further to the right are more frequent in mission statements of Slovenian HE institutions.

Keywords were further clustered into four clusters of sustainability: environmental, social, economic and multidimensional sustainability. The highest numbers of keywords (28 keywords or $43.1 \%$ ) were placed in a cluster of multidimensional sustainability, followed by a social sustainability cluster $(26 ; 40.0 \%)$. Another two clusters, economic sustainability $(7 ; 10.8 \%)$ and environmental sustainability $(4 ; 6.2 \%)$, are of significantly smaller sizes.

In Figure 3, keywords are placed into two-dimensional space where the first dimension represents occurrence in engineering mission statements and the second dimension represents occurrence in other mission statements. The size of each keyword is proportional with its frequency of occurrence. Each keyword is also colored by cluster of sustainability. Keywords that are below the red dash line are more common in engineering mission statements and, vice-versa, keywords above the line are more frequently used in mission statements of other HE institutions.

The environmental sustainability cluster is completely in the domain of mission statements of engineering HE institutions. Similarly, although not so firmly, keywords from the economic sustainability cluster are in the bottom part of Figure 3. Keywords from the largest two clusters, social and multidimensional sustainability, are distributed in both parts of the two-dimensional space.

\subsection{Network Analysis}

From our database, three networks of keywords as actors were established. Network of keywords in all mission statements with engineering and other mission statements separately. Relation in each of them (in a graphical presentation displayed as a link between two actors) is defined as co-occurrence of a pair of actors (keywords) in mission statements. Values on links are determined as the number of co-occurrences of adjacent keywords. 
eng - other

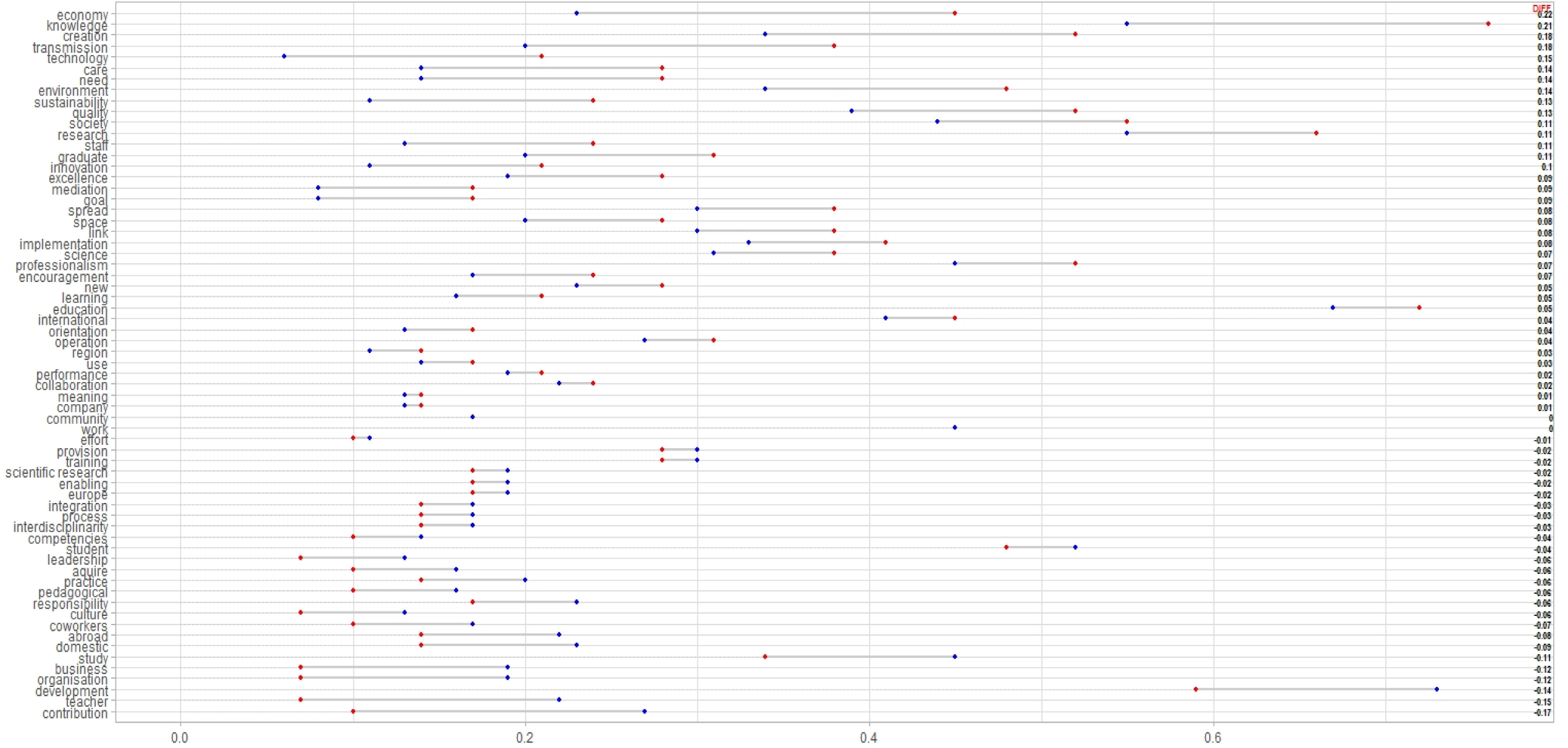

Figure 2. Dumbbell chart of differences of relative frequencies of keywords between engineering and other mission statements in Slovenian HE institutions. 


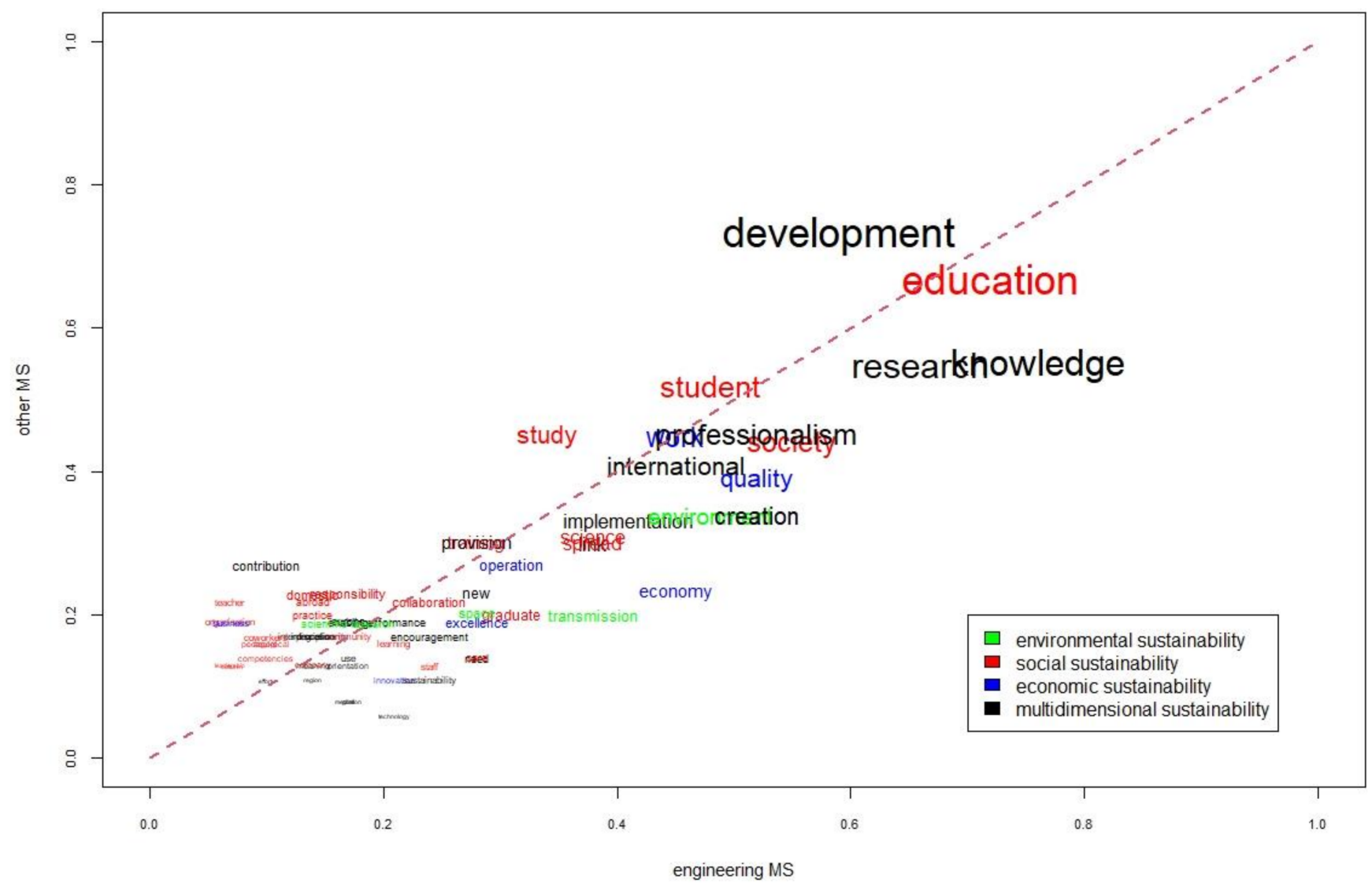

Figure 3. Two-dimensional representation of keywords in Slovenian HE mission statements based on their frequency and sustainability clustering.

Obtained networks are very dense. Density (no loops allowed) calculates the percentage of all possible links in a network. In a network of keywords in all mission statements, density is a high as $98.3 \%$. Average degree is 62.9 , therefore, on average, a keyword is linked with almost 63 other keywords (of 64 possible). In the engineering network there are $83.9 \%$ possible links, and the average degree is 53.7 . In a network of other mission statements, density reaches $93.8 \%$ and the average degree is 60.0 .

The link with the highest weight value (48) in a network of keywords of all mission statements is connecting keywords "education" and "development". It is followed by two links adjacent to keyword "research" ("research"-_development": 45 , and "research""knowledge": 40). In Table 1, we can find links with the highest 25 weight values. For each pair of keywords in Table 1, we additionally calculated weights on links in networks of engineering and other mission statements, respectively.

The same link, "education"-"development", is the most common also in the network of mission statements of other HE institutions, but shares only ranks between 5 and 13 in the network of mission statements of engineering HE institutions. In Table 1, the most missing link is "creation"-"knowledge", sharing the second and third rank in engineering networks but it is not between the 25 most common links in the network all mission statements. Similarly, a link is observed with "development"-“student", which is very common in other mission statements but no so much in engineering mission statements.

For visualization of dense networks, some solutions were developed in the past, e. g., minimum spanning tree, backbone algorithm, PathFinder algorithm and others. PathFinder algorithm preserves the skeleton of the network [42] and was already used in similar analyses $[43,44]$. Network of keywords in all mission statements after applying PathFinder algorithm is displayed in Figure 4. Vertices in Figure 4 are colored by sustainability clustering. 
Table 1. Weights on links in networks of mission statements.

\begin{tabular}{|c|c|c|c|c|c|c|}
\hline Link & Wall $^{1}$ & Rall $^{2}$ & Weng $^{3}$ & Reng ${ }^{4}$ & Woth ${ }^{5}$ & Roth $^{6}$ \\
\hline education-development & 48 & 1 & 13 & $5-13$ & 35 & 1 \\
\hline research-development & 45 & 2 & 13 & $5-13$ & 32 & 2 \\
\hline research-knowledge & 40 & $3-4$ & 17 & 1 & 23 & $9-12$ \\
\hline development-knowledge & 40 & $3-4$ & 14 & 4 & 26 & $4-5$ \\
\hline education-research & 39 & $5-6$ & 13 & $5-13$ & 26 & $4-5$ \\
\hline education-knowledge & 39 & $5-6$ & 15 & $2-3$ & 24 & $6-8$ \\
\hline society-development & 37 & 7 & 13 & $5-13$ & 24 & $6-8$ \\
\hline development-student & 36 & $8-9$ & 8 & 68-102 & 28 & 3 \\
\hline development-professionalism & 36 & $8-9$ & 12 & $14-19$ & 24 & $6-8$ \\
\hline student-knowledge & 35 & $10-11$ & 13 & $5-13$ & 22 & $13-14$ \\
\hline education-professionalism & 35 & $10-11$ & 13 & $5-13$ & 22 & $13-14$ \\
\hline work-development & 33 & 12 & 10 & $27-41$ & 23 & $9-12$ \\
\hline society-education & 32 & 13 & 13 & $5-13$ & 19 & $23-30$ \\
\hline work-education & 31 & $14-17$ & 11 & $20-26$ & 20 & $19-22$ \\
\hline professionalism-knowledge & 31 & $14-17$ & 12 & $14-19$ & 19 & $23-30$ \\
\hline research-student & 31 & $14-17$ & 10 & $27-41$ & 21 & $15-18$ \\
\hline education-quality & 31 & $14-17$ & 13 & $5-13$ & 18 & $31-36$ \\
\hline work-knowledge & 30 & $18-21$ & 11 & $20-26$ & 19 & $23-30$ \\
\hline education-student & 30 & $18-21$ & 7 & $103-139$ & 23 & $9-12$ \\
\hline society-knowledge & 30 & $18-21$ & 13 & $5-13$ & 17 & $37-40$ \\
\hline quality-development & 30 & $18-21$ & 10 & $27-41$ & 20 & $19-22$ \\
\hline society-student & 29 & $22-25$ & 9 & $42-67$ & 20 & $19-22$ \\
\hline development-study & 29 & $22-25$ & 6 & $140-207$ & 23 & $9-12$ \\
\hline work-student & 29 & $22-25$ & 8 & 68-102 & 21 & $15-18$ \\
\hline environment-development & 29 & $22-25$ & 10 & $27-41$ & 19 & $23-30$ \\
\hline
\end{tabular}

${ }^{1}$ Weight on the link in network of all mission statements; ${ }^{2}$ rank of the link in network of all mission statements; ${ }^{3}$ weight on the link in network of engineering mission statements; ${ }^{4}$ rank of the link in network of engineering mission statements; ${ }^{5}$ weight on the link in network of other mission statements; ${ }^{6}$ rank of the link in network of other Mission statements.

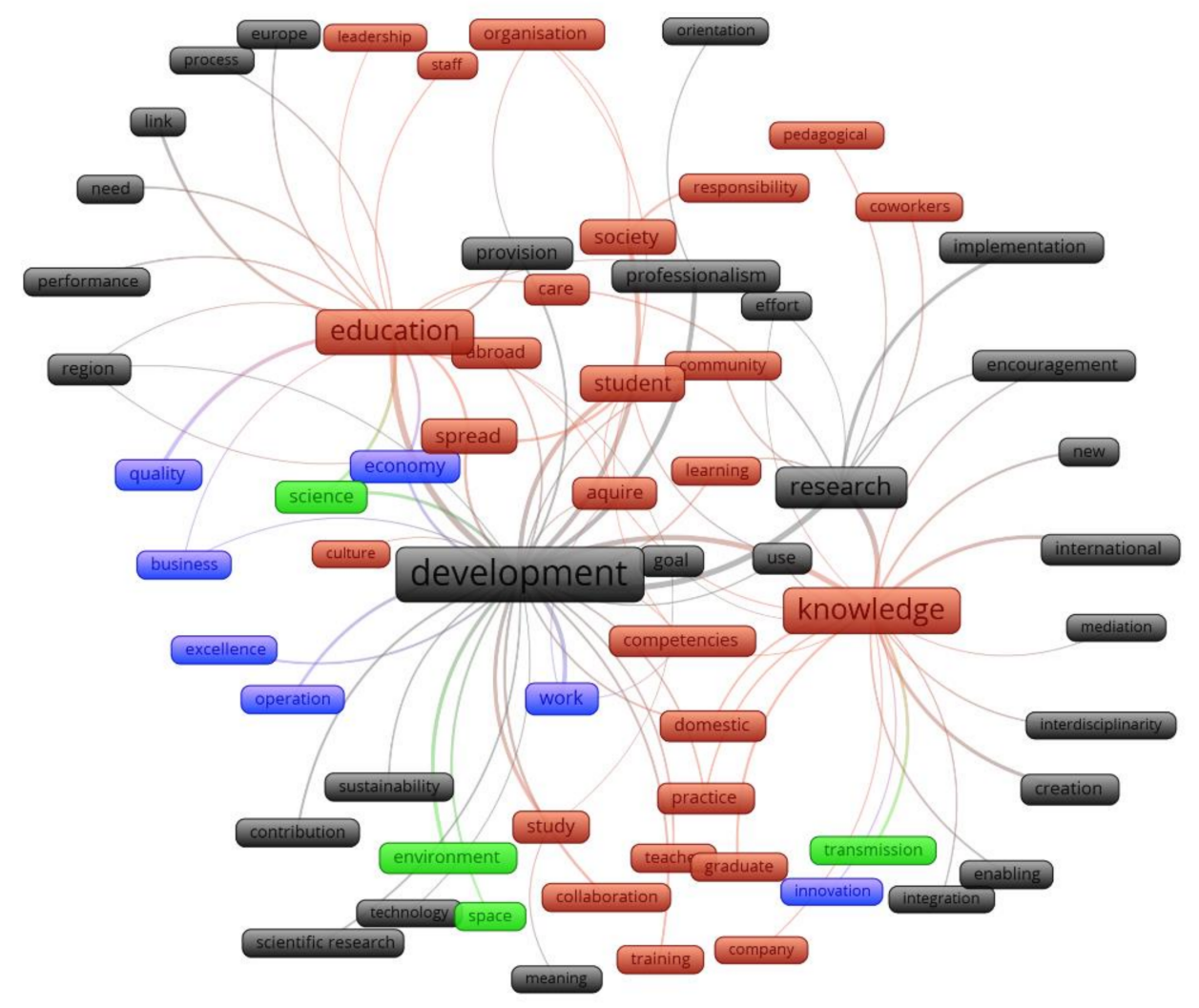

Figure 4. Network of keywords in Slovenian HE mission statements. 
As the most important keyword in Figure 4, the word "development" can be recognized. Some other group centers are "knowledge", "education" and "research". Keywords "knowledge" and "education" are from the social sustainability cluster, "development" and "research" are from the multidimensional sustainability cluster.

Traditional centrality measures in the network of keywords of mission statements in engineering and other HE institutions were calculated. Results of 25 keywords with the highest centrality values are displayed in Table 2 and ordered by weighted degree in the network of keywords of all mission statements. The keyword "development" is on top, as the sum of weights on links related to the vertex representing this keyword (this measure is called also weighted degree) is the highest. Similarly, we can observe that "development" is absolutely dominant in the network of other mission statements. However, this is not so clear in the engineering network. In the engineering network, "knowledge" and "education" share higher values on all three centrality measures compared to "development". On the other hand, the keywords "development", "research", "work" and "international" share significantly higher centrality values in others network.

Table 2. Centrality measures of keywords in networks of engineering and others Slovenian HE mission statements.

\begin{tabular}{|c|c|c|c|c|c|c|c|}
\hline Keyword & Wall $^{1}$ & Weng $^{2}$ & Woth $^{3}$ & Ceng 4 & Coth 5 & Beng $^{6}$ & Both $^{7}$ \\
\hline development & 723 & 79 & 620 & 0.51613 & 0.75294 & 0.08828 & 0.87254 \\
\hline knowledge & 355 & 241 & 125 & 0.69565 & 0.49231 & 0.42076 & 0.16709 \\
\hline education & 343 & 202 & 125 & 0.64000 & 0.49612 & 0.28879 & 0.17869 \\
\hline research & 201 & 52 & 109 & 0.46377 & 0.46377 & 0.01119 & 0.06163 \\
\hline student & 98 & 61 & 57 & 0.50000 & 0.45714 & 0.04720 & 0.05720 \\
\hline spread & 75 & 25 & 15 & 0.40252 & 0.43243 & 0.00234 & 0.00000 \\
\hline society & 66 & 85 & 38 & 0.55172 & 0.43836 & 0.05956 & 0.03125 \\
\hline work & 52 & 32 & 48 & 0.39264 & 0.44755 & 0.03255 & 0.04483 \\
\hline science & 50 & 31 & 17 & 0.42384 & 0.43243 & 0.00037 & 0.00000 \\
\hline acquire & 50 & 30 & 24 & 0.45714 & 0.46715 & 0.01513 & 0.00457 \\
\hline professionalism & 47 & 70 & 34 & 0.47059 & 0.44444 & 0.02508 & 0.01223 \\
\hline study & 46 & 37 & 35 & 0.44138 & 0.43836 & 0.01138 & 0.03125 \\
\hline provision & 46 & 28 & 13 & 0.43836 & 0.43243 & 0.00382 & 0.00000 \\
\hline economy & 44 & 21 & 12 & 0.42384 & 0.43243 & 0.00112 & 0.00000 \\
\hline competencies & 36 & 24 & 8 & 0.46377 & 0.31068 & 0.01923 & 0.00000 \\
\hline use & 33 & 20 & 7 & 0.44138 & 0.43243 & 0.00163 & 0.00000 \\
\hline quality & 31 & 41 & 20 & 0.46043 & 0.43243 & 0.00793 & 0.00000 \\
\hline domestic & 30 & 36 & 33 & 0.53782 & 0.46377 & 0.02411 & 0.00314 \\
\hline organization & 30 & 22 & 9 & 0.48855 & 0.31527 & 0.03146 & 0.00000 \\
\hline abroad & 30 & 36 & 12 & 0.53782 & 0.30622 & 0.02411 & 0.00000 \\
\hline environment & 29 & 14 & 19 & 0.41558 & 0.43243 & 0.00000 & 0.00000 \\
\hline international & 29 & 33 & 54 & 0.46377 & 0.47059 & 0.01252 & 0.03299 \\
\hline practice & 28 & 12 & 11 & 0.47761 & 0.43243 & 0.00192 & 0.00000 \\
\hline care & 28 & 11 & 16 & 0.42384 & 0.34973 & 0.00047 & 0.00325 \\
\hline goal & 28 & 12 & 5 & 0.48485 & 0.32161 & 0.00111 & 0.00000 \\
\hline
\end{tabular}

${ }^{1}$ Weighted degree in network of all mission statements; ${ }^{2}$ weighted degree in network of engineering mission statements; ${ }^{3}$ weighted degree in network of others mission statements; ${ }^{4}$ closeness centrality in network of engineering mission statements; ${ }^{5}$ closeness centrality in network of other mission statements; ${ }^{6}$ betweenness centrality in network of engineering mission statements; ${ }^{7}$ betweenness centrality in network of others mission statements.

\section{Discussion and Conclusions}

To answer the research question on the content of mission statements in Slovenian HE institutions, different approaches were applied. A set of all words was filtered and keywords were analyzed. The most frequently used were recognized: "development", "education", "knowledge", "research". The keyword "development" is dominant in other HE institutions, with the other three more equally distributed between engineering and other HE institutions, although with slight preference to engineering. This was confirmed with network analytic procedures. These four keywords form six of the most frequent links in the obtained networks. 
Keywords of Slovenian HE institutions were further classified into four dimensions of sustainability: environmental, economic, social and multidimensional sustainability, based on the definitions of environmental, social and economic sustainability [29]. The most represented sustainability dimensions in Slovenian HE institutions mission statements are multidimensional sustainability (development, research, ... ) and social sustainability (education, knowledge,... ), while the indicators of economic and environmental sustainability are less common. These results agree with the findings of Dues et al. [26]. "Development", "research" and "knowledge" were discovered among the main words of the mission statements of Brazilian Universities. Based on this, our Hypothesis 1, that dimensions of sustainability are equally distributed in mission statements of Slovenian HE, is not supported.

Comparison of occurrence of keywords between engineering and other HE institutions followed by construction of separate networks revealed some interesting results. All four environmental keywords are more common in engineering HE institutions, which supports hypothesis H2a. The most frequent keyword, "development", is very dominant in the other network, which was confirmed also with centrality measures analysis. The network of keywords in engineering HE institutions does not have so dominant a single keyword as "development" in the other network. Moreover, in the engineering network, the words' centrality measures are more equally distributed (Table 2). Keywords "development", "knowledge", "student", "spread" and "society" are from the social sustainability cluster and form the basis of other networks. On the other hand, they are less exposed in the engineering network and therefore support our hypothesis H2b. The link between "creation" and "knowledge" seems to be very important in the engineering network, but almost unnoticeable in the other network. As $\mathrm{H} 2 \mathrm{a}$ and $\mathrm{H} 2 \mathrm{~b}$ were supported, we can also accept our second hypothesis claiming that mission statements in engineering HE have different sustainability focuses in comparison to non-engineering $\mathrm{HE}$.

This work represents one of the first studies analyzing the mission statements of $\mathrm{HE}$ institutions in the engineering sector (and comparison to the non-engineering sector). Future work on the topic can compare the content of mission statements of engineering and other HE institutions worldwide. With this extension, we believe that using properties of HE institutions network modeling can be a serious option to consider. Additionally, in the past, some papers compared the content of mission statements with visions and values of institutions which can be feasible in this context.

Author Contributions: Conceptualization, K.B. and J.Z.; methodology, K.B.; software, K.B.; validation, K.B., K.M.Y.L. and J.Z.; formal analysis, K.B.; investigation, J.Z.; resources, J.Z.; data curation, K.B. and J.Z.; writing — original draft preparation, K.B. and J.Z.; writing—review and editing, K.M.Y.L.; visualization, K.B.; supervision, K.M.Y.L.; project administration, K.B.; funding acquisition, K.M.Y.L. All authors have read and agreed to the published version of the manuscript.

Funding: This research received no external funding.

Institutional Review Board Statement: Not applicable.

Informed Consent Statement: Not applicable.

Data Availability Statement: All mission statements are available and can be downloaded from websites of Slovenian HE institutions.

Conflicts of Interest: The authors declare no conflict of interest.

\section{References}

1. Conway, T.; Mackay, S.; Yorke, D. Strategic Planning in Higher Education. Int. J. Educ. Manag. 1994, 8, 29-36. [CrossRef]

2. Kosmützky, A.; Krücken, G. Sameness and Difference. Int. Stud. Manag. Organ. 2015, 45, 137-149. [CrossRef]

3. Law, K.M.Y.; Chuah, K.B. What Motivates Engineering Students? A Study in Taiwan. Int. J. Eng. Educ. 2009, 25, 1068-1074.

4. Law, K.M.Y.; Sandnes, F.E.; Jian, H.L.; Huang, Y.P. A Comparative Study of Learning Motivation among Engineering Students in South East Asia and Beyond. Int. J. Eng. Educ. 2009, 25, 144-151.

5. Sufi, T.; Lyons, H. Mission statements exposed. Int. J. Contemp. Hosp. Manag. 2003, 15, 255-262. [CrossRef] 
6. Bart, C.K.; Bontis, N.; Taggar, S. A model of the impact of mission statements on firm performance. Manag. Decis. $2001,39,19-35$. [CrossRef]

7. Drucker, P. Management. Tasks, Responsibilities, Practices. Econ. J. 1975, 85, 195. [CrossRef]

8. Tarnow, E. A recipe for mission and vision statements. IEEE Trans. Dependable Secur. Comput. 2001, 44, 138-141. [CrossRef]

9. King, D.L.; Case, C.J.; Premo, K.M. An International Mission Statement Comparsion: United States, France, Germany, Japan, and China. Acad. Strateg. Manag. J. 2012, 11, 93-120.

10. Hirota, S.; Kubo, K.; Miyajima, H.; Hong, P.; Park, Y.W. Corporate mission, corporate policies and business outcomes: Evidence from Japan. Manag. Decis. 2010, 48, 1134-1153. [CrossRef]

11. Bart, C.K. The Relationship between Mission Statements and Firm Performance: An Exploratory Study. J. Manag. Stud. 1998, 35, 823-853. [CrossRef]

12. Pearce, J.A.; David, F. Corporate Mission Statements: The Bottom Line. Acad. Manag. Perspect. 1987, 1, 109-115. [CrossRef]

13. DeSmidt, S.; Prinzie, A.; Decramer, A. Looking for the value of mission statements: A meta-analysis of 20 years of research. Manag. Decis. 2011, 49, 468-483. [CrossRef]

14. James, H.; Huisman, J. Missions statements in Wales: The impact of markets and policy on congruence between institutions. J. High. Educ. Policy Manag. 2009, 31, 23-35. [CrossRef]

15. Holosko, M.J.; Winkel, M.; Crandall, C.; Briggs, H. A Content Analysis of Mission Statements of Our Top 50 Schools of Social Work. J. Soc. Work. Educ. 2015, 51, 222-236. [CrossRef]

16. Scott, J.C. The Mission of the University: Medieval to Postmodern Transformations. J. High. Educ. 2006, 77, 1-39. [CrossRef]

17. Morphew, C.; Hartley, M. A Thematic Analysis of Rhetoric Across Institutional Type. J. High. Educ. 2006, 77, 456-471. [CrossRef]

18. Meacham, J.; Barrett, C. Commitment to Diversity in Institutional Mission Statements. Divers. Dig. $2003,7,9$.

19. Fugazzotto, S.J. Mission Statements, Physical Space, and Strategy in Higher Education. Altern. High. Educ. 2009, 34, 285-298. [CrossRef]

20. Lowman, R.L. Leading the 21st-century college and university: Managing multiple missions and conflicts of interest in higher education. Psychol. J. 2010, 13, 237-243. [CrossRef]

21. Velazquez, L.; Munguia, N.; Platt, A.; Taddei, J. Sustainable university: What can be the matter? J. Clean. Prod. 2006, 14, 810-819. [CrossRef]

22. Brundtland Comission (World Commission on Environmental and Development). Our Common Future; Oxford University Press: Oxford, UK, 1987.

23. Arcimaviciene, L. EU Universities' Mission Statements. SAGE Open 2015, 5. [CrossRef]

24. UN Decade of ESD. Available online: https://en.unesco.org/themes/education-sustainable-development/what-is-esd/undecade-of-esd (accessed on 26 April 2021).

25. Hasim, M.S.; Hashim, E.A.; Ariff, N.R.M.; Sapeciay, Z.; Abdullah, A.S. Commitment to sustainability: A content analysis of website for university organisations. IOP Conf. Series Earth Environ. Sci. 2018, 117, 012046. [CrossRef]

26. Deus, R.; Battistelle, R.; Silva, G.H.R. Sustainability insights from the mission statements of leading Brazilian Universities. Int. J. Educ. Manag. 2016, 30, 403-415. [CrossRef]

27. Lopez, Y.P.; Martin, W.F. University Mission Statements and Sustainability Performance. Bus. Soc. Rev. 2018, 123, 341-368. [CrossRef]

28. Hart, D.D.; Buizer, J.L.; Foley, J.A.; Gilbert, L.E.; Graumlich, L.J.; Kapuscinski, A.R.; Kramer, J.G.; Palmer, M.A.; Peart, D.R.; Silka, L. Mobilizing the power of higher education to tackle the grand challenge of sustainability: Lessons from novel initiatives. Elem. Sci. Anth. 2016, 4, 000090. [CrossRef]

29. Székely, N.; vom Brocke, J. What can we learn from corporate sustainability reporting? Deriving propositions for research and practice from over 9500 corporate sustainability reports published between 1999 and 2015 using topic modelling technique. PLoS ONE 2017, 12, e0174807. [CrossRef]

30. Social Sustainability-Everything You Need to Know. Diversity for Social Impact, 2021. Available online: https: / diversity.social/ social-sustainability / (accessed on 9 May 2021).

31. Choy, Y.K. Global Environmental Sustainability: Case Studies and Analysis of the United Nations' Journey toward Sustainable Development; Elsevier: Amsterdam, The Netherlands, 2020; ISBN 9780128224199.

32. García, N.G.; Fernández, J.M.; Fitz, C. Environmental Scenario Analysis on Natural and Social-Ecological Systems: A Review of Methods, Approaches and Applications. Sustainability 2020, 12, 7542. [CrossRef]

33. Rosen, M.A. Engineering Sustainability: A Technical Approach to Sustainability. Sustainability 2012, 4, 2270-2292. [CrossRef]

34. Bell, S.; Chilvers, A.; Hillier, J. The socio-technology of engineering sustainability. In Proceedings of the Institution of Civil Engineers-Engineering Sustainability; Thomas Telford Ltd.: London, UK, 2011; Volume 164, pp. 177-184.

35. Felgueiras, M.C.; Rocha, J.S.; Caetano, N. Engineering education towards sustainability. Energy Procedia 2017, $136,414-417$. [CrossRef]

36. Breznik, K.; Rezk, H. The Mission Statements of Public Research Centres in Egypt. World Trans. Eng. Technol. Educ. 2017, 15, 6.

37. Feinerer, I.; Hornik, K.; Meyer, D. Text Mining Infrastructure inR. J. Stat. Softw. 2008, 25, 1-54. [CrossRef]

38. Mrvar, A.; Batagelj, V. Analysis and visualization of large networks with program package Pajek. Complex Adapt. Syst. Model. 2016, 4, 6. [CrossRef] 
39. Van Eck, N.J.; Waltman, L. Visualizing Bibliometric Networks. In Measuring Scholarly Impact: Methods and Practice; Ding, Y., Rousseau, R., Wolfram, D., Eds.; Springer International Publishing: Cham, Switzerland, 2014; pp. 285-320. ISBN 978-3-319-10377-8.

40. Law, K.M.; Breznik, K. What do airline mission statements reveal about value and strategy? J. Air Transp. Manag. 2018, 70, 36-44. [CrossRef]

41. Breznik, K.; Law, K. What do mission statements reveal about the values of top universities in the world? Int. J. Organ. Anal. 2019, 27, 1362-1375. [CrossRef]

42. Chen, C.; Morris, S. Visualizing evolving networks: Minimum spanning trees versus pathfinder networks. In Proceedings of the IEEE Symposium on Information Visualization 2003 (IEEE Cat. No.03TH8714); Institute of Electrical and Electronics Engineers (IEEE): Piscataway, NJ, USA, 2004; pp. 67-74.

43. Law, K.M.; Breznik, K.; Ip, W. Using Publicized Information to Determine the Sustainable Development of 3-PL Companies. J. Glob. Inf. Manag. 2021, 29, 199-216. [CrossRef]

44. Babnik, K.; Breznik, K.; Dermol, V.; Trunk Širca, N. The Mission Statement: Organisational Culture Perspective. Ind. Manag. Data Syst. 2014, 114, 612-627. [CrossRef] 